\title{
FEATURES OF THE OUN NATIONAL LIBERATION MOVEMENT GENERATION IN THE TERRITORY OF THE RAVSKA DISTRICT
}

\section{Serhii Koniukhov ${ }^{1}$}

DOI: https://doi.org/10.30525/978-9934-588-53-2-32

Abstract. The methods of the OUN at the beginning of World War II were determined by the historical circumstances. The opposition of the OUNs to the Polish authorities changed to the opposition to the occupying Soviet authorities. Because the Soviet authorities were wary of those who had already established themselves as anti-Polonization fighters (already considered nationalists and automatically fighters against the Soviet regime; they and their families were taken out of Western Ukraine), Ukrainian nationalists were forced to act underground. Their participation in the national liberation movement was mainly determined by the leadership of the OUN. Members of the OUN conducted mostly public outreach work in the Ravska district, distributing leaflets promoting the national idea in 1939-1941. The purpose of the work is to investigate the peculiarities of the resistance of Ukrainian nationalists to the occupation regimes in the territory of the Ravska district of the OUN before World War II and to analyze the organizational and military-political activities of the OUN. However, OUN activists studied weapons, tried to reach a professional level in all sectors of the economy. All the evidence was that the OUN in the territory of the Ravska district aimed to move from underground activities to armed resistance to the occupier. During the same period from September 1, 1939 to June 22, 1941, no organized armed demonstrations by the OUN in Zhovkva and Ravska district were observed. This indicates that the OUN, in the early stages of World War II, formed a plan for its radical actions of resistance to the invaders.

\section{Introduction}

It is very important to note that Ukrainians, from a historical point of view, became a state people more than a thousand years ago. Although their

${ }^{1} \mathrm{PhD}$ in History, Assistant Lecturer at Department of Museology and Cultural Heritage, National University «Lviv Polytechnic», Ukraine 
national state tradition was repeatedly suppressed and torn apart by the force of external enemies, nevertheless it was always alive in the minds of the people, the source of its strength in the struggle for liberation.

In the 1920s, the Ukrainian liberation movement in western Ukraine used all the forms and methods of struggle available to it, both peaceful and revolutionary-combat. Having formed the political current of the OUN, Ukrainian nationalists actually became an armed force, and representatives of political parties wanted to use it to use force against the Poles. Therefore, in the early 1930's. the consolidated efforts of all Western Ukrainian political forces in the development of the national liberation struggle can be seen. Historical works about the resistance of Ukrainian nationalists to the occupation regimes in Ukraine and in the territory of the Ravska district highlight issues related to the conduct of military operations and campaigns with a military organization, with measures taken by Ukrainians for the purpose of national - liberation struggle for independence of Ukraine.

It should be noted that modern researchers take into account the various explorations, which examine the historical processes of World War II, and actively analyze already known developments.

In our opinion, the question of the resistance of the Ukrainian nationalists to the occupation regimes on the territory of the Ravska district of the OUN should be considered in relation to the main tendencies of the historical development of the national movement in general. This approach will allow to draw conclusions about the state-building potential of the Ukrainian national forces. Against this background, studies that look at how the national liberation spirit of our nation was shaped, how the ranks of Ukrainian patriots grew and strengthened are valuable. These aspects were addressed in the works of O. Pavlyshyn, «Lviv Region in the Age of the Western Ukrainian People's Republic (1918-1919)» [20].

\section{Analysis of research and publications}

The armed opposition of the OUN and UPA troops against totalitarian regimes has been explored by historians M. Lytvyn, I. Patryliak [23], P. Mirchuk [15], O. Lutsky, K. Naumenko [11]. Using rich factual material, they highlighted the heroism, self-sacrifice, and unyielding national spirit of the Ukrainian underground groups of the OUN and UPA, who fought for an independent Ukrainian state. Historians M. Lytvyn, O. Lutsky, 
K. Naumenko traced the opposition to the Soviet regime in Western Ukraine since 1939 [11].

I. Patrylak paid more attention to the confrontation in Ukraine in general and took note of the years 1943-1945. He considered the struggle between the UPA and the Soviet guerrillas: "The fundamentally different goals of the Ukrainian rebels and the Soviet guerrillas led to war between these movements during the Hitler occupation. The OUN's sought to create an independent Ukrainian state by conquering the native lands from the invaders; instead, the red partisans fought against the Germans and nationalists for the restoration of Soviet power in the USSR. Because of these differences, it was extremely difficult for the two sides to find an understanding, even in the possible joint struggle against the Nazis" [22, p. 388]. Describing the UPA's clashes with separate units of the Red Army and the confrontation with the NKVD in 1944-1945, I. Patryliak used not only documents but also diaries of Ukrainian rebels [22, p. 412]. Scientist I. Patryliak cites the text of a leaf let distributed by Ukrainian nationalists: "The Ukrainian people! German-Nazi occupiers flee from Ukraine. They are replaced by the same Stalin-Bolshevik invaders. With the change of the occupier in Ukraine nothing has changed" [22, p. 142]. The historian concluded that although the hard-fought and uncompromising struggle of Ukrainian nuns with the most powerful state of post-war Europe continued for more than ten years after the end of the war, but the first two years of confrontation were perhaps the bloodiest [22, p. 442]. I. Patryliak confirmed his research with statistics.

In the P. Mirchuk's work «The Ukrainian Insurgent Army (1942-1952)» repeatedly mentions the Zhovkiv and Rava-Ruska districts that were part of the Ravska district. Describing the occupation period of 1944 P. Mirchuk in order to demonstrate the robbery of the Ukrainian population by the Soviet authorities, use statistics concerning the Lviv region in general and the territories around Zhovkva in particular and it shows us that the bread and meat contingents at the time were excessively high [14, p. 96]. This, of course, was one of the reasons for the opposition to the occupying USSR. P. Mirchuk also emphasizes other causes of resistance. He analyzes the management of the Bolshevik son Ukrainian soil, which also established "forestrules" (imposing a duty on the village to harvest 1000-1200 cubic meters of wood during the month), monetary taxes, neglecting sanitary standards, which led 
to massive diseases for typhoid and others. P. Mirchuk traces the activities of the Soviet authorities in different directions: demonstrates treachery in the attitude towards peasants, workers, intellectuals, points to methods of influencing different spheres of society: culture, language, church, etc. and it is concluded that the Bolsheviks used all possible means of extermination of the Ukrainian people and Ukrainian culture, their methods of terror were continuous searches, arrests, removal of people, robbery, murder, destruction of «kulak farms», public torture. In such a situation, the only insurgent of the Ukrainian people was the Ukrainian Insurgent Army (UPA) [14, p. 105]. Considering the tactics of the UPA's struggle against the Soviet authorities, P. Mirchuk states that the UPA practiced raids widely. The author provides many examples of such raids. Among them is the 1945 raid that sent three hundred "Kholodnoyartsi" soldiers under the command of Grad and Grizny leaders from Zhovkva in the territory of north western Transcarpathia [14, p. 97]. P. Mirchuk's studies show that in the Zhovkiv and Rava-Rutska districts, as well as in any other districts of Western Ukraine, harassment was exerted by the Soviet authorities, so in these territories, as in all Ukraine, there was growing dissatisfaction with the occupation regime, which prompted before the fight.

The fight against Soviet power is also discussed in the essay «Zhovkivshchyna». In 1939-1941, a Soviet OUN rebelled against Soviet power, led by Zavada Stepan (pseudonym "Kozhumyaka"), a native of Zavad's settlement, who belonged to the village. Nova Skvariava [5, p. 209]. In the essay «Zhovkivshchyna» the attention was paid to the improvement of the organizational structure of the national underground, the branching of the district OUN of Zhovkivshchyna, headed by V. Gotiy, was analyzed in detail. Actually, the city of Zhovkva, according to the authors of the essay, had the status of a district leader. Each district lead consisted of 2-3 subdistricts (bushes), which were subordinated to 6-7 rural organizations (villages). In total, 45 villages operated in Zhovkva district [5, p. 232]. The "Zhovkivshchyna" essay proves that the struggle against the occupation regime was practiced in every county, in every smallest settlement.

Studies on the OUN's activities in the Ravska district indicate that Ukrainian nationalists resisted the invaders in different ways: both weapons and words. O. Stasiuk's monograph «Underground printing houses of the OUN (1941-1953)» has investigated that despite the armed resistance 
during the period under review, the activities of the propaganda system of resistance of Ukrainian nationalists have also intensified; the researcher covered the system of functioning of the underground OUN printing houses in the Ukrainian lands under the conditions of Nazi and Soviet occupation [28]. O. Stasyuk pointed out that the "Prague" printing house near Zhovkva was one of the most powerful at the time. The paper describes in detail the process of setting up this printing press, states that local underground workers in 1941 were tasked with finding a place for its arrangement, and at the same time created a group for security and transportation (in disassembled form it was in Kulykiv in 1942, then It was relocated to a hamlet Jury Skiry at Mokrotin) [5, p. 19-20]. In 1943 it was transferred to the village Stilsko of Mykolaiv district and thanks to it, since 1942, published the magazine «Idea and rank», printed invocations and communications of the OUN Wire $[5$, p. 36]. The monograph also points to the fact that the propaganda activities of the OUN were facilitated by the population of the Ravska district: the cover for the printing house of the OUN (b) «Prague» was in the stool of one of the owners of the village of Mokrotyn, the entrance to it was disguised as a pit for potato storage [5, p. 58]. In circumstances of violent confrontation with the occupation system, nothing could guarantee security, so there was a need for frequent changes in the location of the printshop. O. Stasyuk notes the right tactics of the organizers of the Zhovkva printing house, who managed to avoid arrest or liquidation for a longer time [28, p. 62].

The importance of the printing press for combating the occupation regime is evidenced by at least the fact that the head of the Ukrainian nationalists Dmytro Mayivsky supervised this printing press. We believe that there alfighters against the occupiers were simply the employees of the underground printing company. O. Stasyuk gives their names and positions in a special table [28, p. 148]. The researcher once again confirms that the OUN printing houses (including Zhovkva and Ravska disrict) played a major role in the comprehensive fight against the occupation regime.

Contemporary Ukrainian historiography also affirms the tradition of dividing the Resistance Movement in Ukraine by national currents, although the lack of common terminology hinders the formation of such an approach. Thus, historians O. Subtelnyi, F. Turchenko, Y. Gritsak, V. Semenenko, and L. Radchenko, L. Kormich, and V. Bagatsky distinguish two major political 
movements in the Russian resistance in Ukraine, one of which was guided by Soviet slogans, and the other focused on the creation of an independent Ukraine $[2 ; 8 ; 27 ; 30 ; 31]$.

Historians classify the Resistance Movement differently during the World War II. In particular V. Kosyk distinguishes between the «national» and «Soviet» resistance movements [9], and T. Hunchak - the «communist underground and partisan movement», «the Polish underground and partisan movement», «the Ukrainian independent and partisan movement» [3], V. Stetskevich [29], I. Mukovsky and O. Lysenko emphasize on the «Ukrainian national resistance movement» [10], M. Koval uses the term «Ukrainian resistance movement» [7]. In modern studies one can see that there were two main trends in the resistance movement in Ukraine: the «communist» resistance movement and the «Ukrainian» resistance movement [9].

Our observations indicate that modern historians are trying to objectively evaluate the Soviet-Ukrainian confrontation during World War II. The documents collected and analyzed, the eyewitness testimony, give them the right to conclude that the OUN's sought to conquer their native land from the invaders; Because of these differences, it was extremely difficult for the two sides to find an understanding, even in a possible joint fight against the Nazis.

The differences in the treatment of national liberation resistance of Ukrainians during the World War II can be explained by the fact that the documents on which the conclusions are drawn cannot always be considered as objective or impartial, since these documents often represent only one view of events.

It should be noted that the scientific reconnaissance activities of Ukrainian nationalists in the territory of the Ravska district of the OUN are fragmentary. Historians are often focused on the investigating individual units of the UPA. For example, the work of G. Lupiy [13, p. 6] is devoted to the study of the activity of one of the leaders of the national liberation movement - sotnyk "Em", R. Zinkevich took into account the activities of another head of the national liberation movement during the Second World War - «Zalizniak» [21]. And we also know about the studies of the events that took place in the small settlements of the region. Thus, Yavorivsky, in his historical study of Nova Skvariava, tells us about the UPA which was fighting in a separate village. The author makes extensive use of memoir 
material. He figuratively describes some episodes of wartime, such as the attack by Polish militants on Easter Monday 1943, the fight with the NKWD in July 1944, the raid of the village by the Red Broom of the same year (July 22), the raid of the village by the NKWD on August 19, 1944 [33]. L. Shankovsky told in detail about the battle of hundreds of «Galayda», commanded by the commander "Peremoga" near the village on March 21, 1945 [32]. The authors analyzed not only the tactics of the hundreds of "Galayda", but also the tactics of the command of the Bolshevik brigade. They concluded - a tactical canon of Soviet commanders: «The life of a soldier - a penny» caused the defeat of the Bolshevik brigade in the forest near Zybolky. Rebels from hundreds of UPA «Peremoga» had a clear ideological advantage over the enemy.

A significant contribution to the study of OUN and UPA activity in the territory of the Ravska district during the Second World War is the work of V. Moroz, who reviewed the activities of the WD "Bug" [16] and submitted an analysis of the OUN and UPA underground press in the territory of Lviv region [17].

Analyzed works of modern historians, who examined the events of World War II and the post-war processes, allow us to argue that, in confronting Poles, Germans, Soviet authorities, Ukrainian nationalists put the national idea first.

\section{Formation of Ukrainian Nationalist Armed Forces and preparation to occupation}

In order to understand the OUN activities during World War II on the territory of the Ravska district, it is necessary to find out what influenced the intensification of the national liberation confrontation here in particular: either the actions of the Ukrainian nationalists were caused purely by the political situation existing at that time, or there were other factors that contributed to the growth in the number of the OUN members and encouraged its members to decisive actions against the invaders. It should be noted, that even after the war some villages within the Ravska district were considered fully Bandera-supportive by the Soviet authorities. It is no secret that Mokrotyn, Krekhiv, Zashkiv and others were among such villages. Our task is to find out why it was on the territory of the Ravska district where the national ideas outweighed everything else during World War II 
and where the phenomenon of nationalism originates from in the territory being studied. The historian I. Patryliak quotes the nationalism researcher Benedict Anderson: «The great wars of this century are extraordinary not so much in the unprecedented scale on which they permitted people to kill, as in the colossal numbers persuaded to lay down their lives. Isn't it obvious that the number of people killed... far outweighs the number of those who killed? The idea of the ultimate sacrifice through fatality comes only with the idea of purity. Dying for one's country, which usually one does not choose, a person is gaining moral greatness» [23, p. 502]. These words refer also to those who fought for the national idea in the Ravska district during World War II. To understand what ruled the minds of the Zhovkva nationalists and urged them to fight, to understand why the youth joined the insurgency even though there was no chance of victory then, to explain why this land was so dear to its inhabitants who sacrificed their lives for it, let us turn to the historical background for this region. The Encyclopedia of Ukrainian History states that until 1603 the city, which is now one of the district centers of the Lviv region, was called Vynnyky, then Zhovkva, and then, during the period from 1951 to 1991, Nesterov. Today it is a regionally governed city, the district center in the Lviv region. It is located on the banks of the Svynia River (the Rata River confluent, the Vistula basin), 32 kilometers to Lviv. In 2004, the city population amounted to 13.4 thousand people. The first written mention of Zhovkva dates back to 1368 . Initially, the settlement belonged to a noble Dreventi. Since 1560, it had been in the ownership of the family of the member of Upper House of Diet in Poland, the Zolkiewski family, later the Sobieski and the Radziwill owned the city. In the 17th century, the city became a major trading center. In 1603, it was granted the Magdeburg rights and had the privileges of distilling, trade and a permission to hold four fairs a year. The city development assumed construction using stone. Such famous painters as I. Rutkovych, D. Raievych, V. Petrahnovych worked here in the 17th century. In 1613, an Orthodox fraternity and a school were founded at the Church of the Nativity. According to the hypothesis of I. Krypiakevych, Bohdan Khmelnytsky was born in Zhovkva and later studied here at a fraternal school [6, p. 46]. Since 1994, Zhovkva has become ат architectural conservation area. There are 40 monuments of town planning, architecture and monumental art on its 27 hectares area, 25 of which are of national 
importance, particularly the Zolkiewski-Sobieski Castle being one of the most magnificent in Europe, and the St. Lawrence Church built to the project of the architect P. Schaslyvy and belonging to the best examples of Renaissance construction on the territory of Ukraine [148, p. 163-165]. The Encyclopedia of Ukrainian Studies states that Zhovkva is a city in Galicia, on the border of the Roztochya and Nadbuzhanska bolson; a district center of the Lviv region. In 1931, it had 8,000 inhabitants (apparently, no population census was conducted during World War II, therefore no data on the population number in the period under study are available (S.K.)). At that time, small industry was developed in Zhovkva - glass, food, and brick manufactories.

It is known that at the beginning of World War II, the subdistrict groups of the OUN were acting in the territory of the Ravska district. In order to properly evaluate their behavior, let us find out what initially caused development of the OUN movement in the territory of the Ravska district, what exactly led to creation of these groups and what their purpose was. Let us take a brief look at the social and political situation existing before World War II. After World War I, the western lands of Ukraine came under the influence of Poland, Romania, and Czechoslovakia. Galicia, in particular, was under considerable influence of Poland. The state fate of the western lands of Ukraine was determined by the result of the Ukrainian-Polish war of 1918-1919 unfortunate for the Ukrainians, as well as by the result of the Soviet-Polish war of 1919-1921. The Treaty of Riga, drawn up between the Soviet Russia and Poland in 1921, defined the state border between these two countries along the Zbruch River, across the Volyn region, the Podilia, and further - across Belarus to the Dvina River. Thus, under this treaty, all western lands of Ukraine were under Poland. The future of the western Ukrainian lands was finally determined by the Council of Ambassadors in 1923, which decided to annex the Eastern Galicia to Poland, thus legitimizing with its decision the Polish occupation of the Eastern Galicia. According to the treaty between the Entente states and Poland, the Poles were to carry out only military occupation on the territory of the Eastern Galicia. Poland had no right to introduce its own civil administration here. To the Entente States Poland committed itself to guarantee the Ukrainians the right to use their language in schools and in public life, to secure the right of the three Galician provinces to self-government. In fact, Poland not 
only failed to fulfill these commitments, but instead started implementing a policy of terror, mass detention and exile to concentration camps towards the Ukrainians. In 1919, the Polish occupation authority liquidated all Ukrainian departments in the Lviv University, and made the whole university Polonized. Attack on schools was also noticeable. If in 1918 there were 3,600 state-owned Ukrainian schools in the Eastern Galicia, over the Polish rule their number reduced to only 416. In 1920, the Galicia Diet (Sejm) and the Krajowy Department as autonomous administration of the Eastern Galicia were annulled. The very name «Eastern Galicia» was changed to «Eastern Lesser Poland». Thousands of the Ukrainians - former government officials - were not accepted into public service. A clear political censorship of the Ukrainian press was introduced. A special cooperative law put the Ukrainian cooperation under the Polish governmental control [26, p. 11-13]. Right before World War II, the Galician were deprived of their right to decide their own fate independently. Back at that time the Ukrainian clerisy were struggling to preserve national identity. This is further discussed in the works of I.O. Gavryliv and T. Gryvul [1]. For example, as we learn from their publications, the Ukrainian nationalists, given the challenges of Ukraine's development at that time, believed that the Ukrainian state could only be restored through the national revolution that could be ensured solely by stablishing a national dictatorship. As stated in the scientific work of V. Kosyk, «the strategy of the OUN struggle was originally aimed at revolutionizing and activating the masses» [9]. The OUN leaders thought that the Ukrainian issue could be resolved through decisive radical actions. That is why the OUN members were constantly trained. From the scientific sources and the eyewitness accounts we learn that even before World War II the residents of the Zhovkva experienced national and social injustice from Poland. Teodor Pelekh, the inhabitant of the village Matsoshyn, recalls: «The Poles who came to Galicia acted provocatively and incurred hatred for ill-treatment of the Ukrainian people on the Ukrainian land». Teodor Pelekh tells about the mockery of the Polish gendarmes over the Ukrainians, about the outward attitude that even the ordinary Poles demonstrated to the Ukrainians [24, p. 38]. The inhabitant of the village Nova Skvariava in the Zhovkva district confirms that the Polish authorities effected repression against the Ukrainian people. The Polish chauvinists tried to destroy and ignore all Ukrainian, in order to make the world believe that Galicia is the 
part of the Polish ethnographic lands [4]. The invaders found the publicpolitical figures, the UGA soldiers, the state-building activists, the patriotic clergy and clerisy, peasants and townspeople, arrested them and sent them to the newly created concentration camps in Wadowice, Dąbie, Pikulice, Strzałkowo, Tuchola, Jaliwtsi, Janiw. The Ukrainian institutions, schools, branches of the «Prosvita» Society, the «Silsky Hospodar» Society, the youth organizations «Sokil», «Sich», «Plast», the newspapers were closed. The Ukrainian songs, the trident, the blue-and-yellow flag were forbidden. The Polish authorities tried to effect forced Polonization of the Ukrainian people. Here is the evidence: «A certain Viazivsky had a grocery store in the village Soposhin. The Poles distorted his name to Vyonzowski. A certain Grabovsky lived in the village Machoshyni, his two sons - Fedir and Ivan were the OUN members. Their father had a brother who, in order to get hard physical work on the railroad, had to change his name to Grabowski. Such cases were numerous» [24, p. 39]. The Poles pursued a policy of assimilation. They sought to create the so-called «szlachta zagrodowa» (small Polish gentry), whose members should be persons with last names ending with «ski». The inhabitant of the Zhovkva district D. Nedoviz recalls: "The Polish administration arbitrarily changed the endings in the last names, for example, Sazhynski instead of Sazhynsky. I myself strived for the correct spelling of my last name in the gymnasia, as the Polish administration turned it into «Nedowuz». Arguing with the Polish language professor Ratusinski, I managed to make them spell my name «Nedoviz» again. It was an unpleasant affair. The Polish police intervened and my whole family was involved» $[19$, p. 29]. From the stories of people who were affected by the influence of Poland, it becomes clear that they did not want to change their last names, they defended their right to bear their Ukrainian name. However, to take a certain position in society, for example, to get a job, they had to sacrifice their principles.

Defining the essence of organizational principles in the construction of the OUN, the Congress approved the organizational structure of the OUN. The Legislative Body becomes the Assembly (or Congress) of Ukrainian Nationalists, the executive body - the Lead of Ukrainian Nationalists (PUN). On the territory of Ukraine, the OUN was divided into 10 regions, the region into districts, the district was divided into divisions («stanytsia»), divisions were divided into councils («zveno») (3-5 members). The members 
of the OUN are 21-year-old Ukrainians who have written an application and received a pledge from two members of the Organization and served a 6-month candidate term.

As early as in 1930-1931, the first OUN units were formed in RavaRuska, Zhovkva, Matsoshyn, Zashkiv and other villages of the studied region. Their activities were coordinated by the county executive body, which in 1932 was headed by a printmaker Volodymyr Kasaraba from Zhovkva. In the mid-1930s, the local units (the couple «zveno» of 3-5 people created a «group» or a «herd») were subordinated to the Lviv region and later to the Ravska district of the OUN. The OUN members denied any legal contact with the state authorities and prepared the youth for the future armed rebellion against the occupiers [5, p. 218]. On September 1, 1934, the OUN member Hryhoriy Kulykivets shot the police agent Stanislav Yatsyn near the community hall in Zhovkva. In the same days, an assassination of the well-known cooperator Anton Humen was also attempted, who did not renounce the Soviet philosophy even during the terrible famine in the Upper Dnieper region (the Holodomor). And in October - November there was a landmark case against the organizers of these assaults, which testified to the high agitation-propaganda activity of local nationalists, their authority among the population, especially the radical-minded youth - workers, high school students of public schools, grammar-school pupils, students $[5$, p. 220]. Summarizing the questions about the political ambitions that were formed right before World War II, we can state that the Ukrainians always sought to preserve their language, wanted to manage production and social processes by their own. And they also wanted to live richer and freer lives. They were tired of the Polish authorities' pressure. People living in the Ravska district were by no means outraged by the imperious behavior of the Poles, and so they rallied to resist the Polonization in their native villages. The resident of the village Matsoshyn, Teodor Pelekh, says: «As a young boy, I dreamed of being a monk to live in caves, deserts. When I became a young man, I began to learn a hard life, and then I decided to be just as much as I could and to serve Ukraine» [24, p. 41]. This indicates that the conscious Ukrainians became nationalists.

Teodor Pelekh, who his time (back in 1937) belonged to the reading group of «Prosvita» and was a member of the senior circle of historians, voluntarily joined the OUN squad. Together with him the organization was 
joined by his fellow villagers Volodymyr Roman, Teodor Kyryk, Teodor Hrabovsky. Each of them swore an oath. «Our goal was to demonstrate that we are the masters of our land», - states Teodor Pelekh [24, p. 45]. The OUN members hung national flags on the school's state house, painted out the Polish symbols - opposed Polonization in various possible ways. The number of the OUN members increased. In 1939, Andriy Hrynyk also joined the OUN unit that Teodor Pelekh belonged to. Later on, other guys became the OUN members too: Volodymyr Bohonis, Teodor Didyk, Mykola Hrynyk, Ivan Hrabovsky, Yaroslav Matsko and Mykhailo Pavnyk [24, p. 42]. Thus, the subdistrict unit (group) of the OUN was organized. As can be understood, a negative attitude towards the Polish authorities developed in the territory of the Ravska district even before the outbreak of World War II. Opposition to this authority and intention to resist it gave rise to creation of subdistrict and district groups of the OUN. The organization, which aimed at gaining an independent Ukrainian state in a revolutionary way, properly developed its network. For instance, in the territory of the Western Ukraine there were ten district executive bodies of the OUN. A clear organizational vertical was functioning with the following basic elements: land - area county - district - village. According to the Polish researcher Roman Vysotsky, by that time the number of the OUN in Galicia was about 3000 members, in Volyn - 1,000, excluding the members of the OUN Youth and the sympathizers [25, p. 350]. However, back at the beginning of World War II, the OUN was reorganized in the territory of the Western Ukraine, that reorganization was caused by the need to improve the organization's structure and its governing vertical. The new vertical consisted of the following elements: OUN body - land - region - area - county - district - subdistrict village. The organizational structure of the OUN combined elements of the Polish and Soviet administrative and territorial structures. The boundaries of the areas mostly coincided with the boundaries of the judicial areas of the Polish state, the counties boundaries - with the boundaries of the counties of territorial division existed before 1939, the districts boundaries - with the boundaries of the districts of the Soviet administrative-territorial system. Such reforms of the organization had several advantages: firstly, decentralization of the organizational vertical happened, and secondly, it contributed to strengthening of the conspiracy and the role of the district OUN bodies in the network development. The latter, having 15 to 20 settlements (previ- 
ously the counties controlled 90-100 villages) under their control, could carry out their work more effectively and achieve much better results $[25$, p. 357]. Structural reorganization also affected the region under study. Thus, in the territory of the Ravska district, Dmytro Mayivsky became at the head of the Zhovkva district at the beginning of World War II. Therefore, the main precondition for creation of the subdistrict OUN groups was the Polish authorities' pressure. It was the attempt to resist Polonization that prompted conscious Ukrainians to rally locally and to create subdistrict groups. In 1939, the political situation changed: the Soviet authority replaced the Polish one. At the organizational county meeting (gathering) held at the end of August in the village Matsoshyn, a leading district leader of the OUN, Dmytro Mayivsky, directed the local OUN members: «The Organization of Ukrainian Nationalists (OUN) since its very establishment is clearly focused on the principle that consists in the need for organizing the Ukrainian armed forces to liberate Ukraine from the yoke of various invaders. The German-Polish war is approaching, and we, the Ukrainians, must prepare for the guerrilla war with the Poles, and give the Poles a proper response for all hurt they have caused us». At the second meeting (gathering) in September 1939 Dmytro Mayivsky spoke briefly but convincingly and decisively: «On September 1, Germany invaded Poland. We, the members of the OUN, will fight a guerrilla war against the Poles. We will treacherously and courageously acquire weapons from our enemy. First of all, we will go to the Polish police stations, disarm the police officers and have guns for the beginning» [18, p. 12]. As we can see, the members of the subdistrict OUN group of the village Matsoshyn in particular and the Zhovkva district as a whole in August - September 1939 set fighting the Poles as a priority task. In the meantime, under the leadership of Dmytro Mayivsky, a military camp in the woods near Volya Zhovtanetska was organized. The camp included the OUN members from the surrounding villages: Zibolky, Zheldts, Vereny and others. The purpose of the camp was to act in an organized manner; «to collect and store weapons that the Polish army left in the woods; to provide political and organizational training to young people» [6, p. 209]. The organization of such a military camp proves that the OUN members prepared themselves for possible armed actions against the Poles. By September 1939, the plans for the Ukrainian nationalists counties organization were guided by hatred to the Polish authorities. Also, in the territory 
of the Lubachiv county, which in 1939 was the part of the Ravska district of the OUN (b), military training schools were organized and the OUN departments were formed (b). At the beginning of the war, in the vicinity of Narol, Plazov, Chesanov and Dzikov Stary, the OUN activity was primarily associated with the brothers Ivan and Omelian Hrabets from Nove Selo, as well as the circle of people from Novy and Stary Liublynets: Ivan Bily, Vasyl Levkovych, Ivan Shymansky. It is worth mentioning that in 1944 OmelianHrabets acting under the pseudonym «Father», «Lemko» was one of the main organizers of the Ukrainian underground work in the Podilia area [4, p. 84]. In 1940, the Hrabets brothers organized. Gorayets is the first subdivision - «the youth hut» - in the village Horayets. Such an initiative in Novy and Stary Liublynets was made by Oleksandr Bablak, Ivan Komar, Gryhory Harasym, Mykola Kozak. The members of the «hut» organized cultural and educational life in their native region. They performed during holidays and festivals and arranged sports competitions. Owing to such organization they also managed to carry out underground work, collecting weapons, ammunition and military equipment left over after the events of September 1939. Meanwhile, the Hrabets brothers organized military training camps (semi-official, under the guise of various courses organized through the area delegate offices of the Ukrainian Central Committee (UCC)). VasylLevkovych acting under the pseudonym «Vorony» was one of the participants of such courses [4, p. 84]. At the same time, Omelian Hrabets, as head of the OUN in the Liubachiv district and, at the same time, an employee of the UCC delegate office in Chesanov, had an influence on formation of police departments during the German occupation period. For example, in Chesanov Ivan Shymansky was appointed as commander of the police department [4, p. 147]. Since 1941, many young activists from the Liubachiv district have refocused their activities to expanding the OUN network in the Eastern Ukrainian lands, and the organization's activities in the vicinity of Cesanov, as well as in the neighboring Kholmshchyna, have weakened significantly. At the time of Omelian Hrabets acting as the leader of the OUN in the Rivne region, Ivan Bily acting under the pseudonym «Bureviy» became the leader of the OUN in the Liubachiv district. He died in the battle with the Polish Army (Armia Krajowa) on December 5, 1943. Until January 1945, the last head of the OUN in the Liubachiv district was Ivan Hrabets acting under the pseudonym «Oles», «Harmash» [4, p. 192]. 
Mykhaylo Levus (born in 1926) living in the village Mokrotyn believes: «In order to understand the need for the OUN groups formation, it is necessary «to give an image of the events and conditions of the 1930s and 1940s in which my generation lived, searched for national identity, came to the historical arena and took the burden of fighting for the will of our people». Mykhaylo Levus notes that back in his childhood, his fellow villagers did not want to accept either the Polish orders, or the portraits of the Bolshevistic leaders that appeared in school classes instead of the holy images, or the atheistic interpretations and fairy tales about the bright future offered by teachers under the Soviet rule [12, p. 213]. On the first occasion, in Zhuri, the vicinity of the village Mokrotyn, young Mykhaylo Levus joined the youth organization of the OUN. Here is his story: «At the end of 1942, I joined the youth organization of the OUN. There we studied the Decalogue, the history of Ukraine, trained to march and gained other knowledge. So I joined the military network, where we were taught how to handle weapons of various types and systems, from rifles to stutterers, did marching and rifle drill, trained the ability to fight and, if necessary, retreat, the ability to provide medical assistance, etc. I would like to point out that there prevailed military discipline. To ensure a peaceful life for the civilian population, the OUN organized self-defense units of young volunteers in each and every village. Weapons were taken from the Polish army that capitulated in 1939, from the Russian army in 1941, and even from the Austrian army back from World War I times. By the end of 1943, sotnias (gangs of 100 soldiers) of the UPA were gathering in the woods near Mokrotyn, and I was instructed to maintain communication between them. At that time I seldom was home». M. Pakholok living in Mokrotyn (born in 1932) says the following as to creation of the OUN groups in his native village: «I do not know another village that would conceive the OUN slogan «Gain Independent Unital Ukraine or die struggling for it!» with such sacrifice. And I do not know a family in the village which this way or another suffered from the military misery».

M. Pakholok tells of a nationally conscious family of Hashchuk, who had ten children who had somehow joined the national liberation movement during World War II: “At the OUN's call, its members and supporters collected weapons abandoned by the Poles and traded. Hashchuk's sons did not stay away and took an active part in the event. Their relatives saw it and did not 
mention it, because they knew that no one would give Ukraine the will it must be obtained with a weapon in their hands. With the advent of the Red Army in Halychyna, Hrytsko Hashchuk, on the orders of the OUN, moved to Zakherzonnia on the order, went to military training there and returned in early July 1941 together with the OUN Derivative Groups" [12, p. 238].

Other Gashchuk guys also joined OUN structures. Subsequently, they became active defenders of the region: Fedor Hashchuk «Chumak» headed these self-defense department (SKV). Glinsko, Nova Skvaria, Stara Skvarya, Mikhailo Hashchuk «Snigur» were the participants of one of the fights in Mokrotin.

Gritsko, Mikhail, Ivan, Fedir were members of the OUN and fighters of Mokrotin self-defense. In the early forties, Hashchuk's stoop was full of weapons and ammunition [12, p. 254].

The above evidence also proves that the residents of the Ravska district were actively involved in the implementation of the OUN's top priority tasks. Not only the OUN members but also their sympathizers were selling weapons. People's aspirations to uphold their national and religious traditions determined their priorities. Therefore, the leaders of the OUN did not have to spend much effort to convince the population in their political line.

The basic prerequisite for the establishment of OUN combat groups is a negative attitude towards the Polish authorities, which had developed before the Second World War. However, as we can conclude from the above memories, there al reason behind the creation of subunit OUN groups was dictated by life itself: people wished to defend their religious beliefs and national preferences, they were ready to defend what was most dear to them, from any one the occupier.

The strong desire to live in an independent state prompted the OUN to form an extended network of local boys. Families and friends of these groups became sympathetic and also joined the fight in various ways.

\section{Conclusions}

Our observations suggest that the activities of the established OUN subdistrict groups on the territory of the Ravska district depend on the political situation in the region. When Polish soldiers retreated from the GermanSoviet war and the Bolsheviks came to power in Galicia, who began to change people's lives in the Soviet way, the subunit groups of the OUN 
changed their vision of the task somewhat: now they had the forefront of the fight against Soviet policy.

According to the OUN, the most effective means were underground activities and armed struggle. According to the concept of nationalists, the main directions of the permanent revolution were: political education of the masses and the popularization of the main - the restoration of the Ukrainian independent state; deployment of hostilities against the occupiers on Ukrainian lands; constant branching and strengthening of the OUN structural network; total strengthening of the revolutionary spirit in the public; until the «breakthrough moment» - the uprising.

The successful military-political activity of the Ukrainian nationalists was based on the strict organizational structure, high-qualied and disciplined stuff, and, of course, well-organised and worked on ideological and educational policy. All the measures operated during the interwar period had allowed OUN to mobilize considerable part of the Ukrainian association to the armed fight not only in the World War II but after it as well.

In 1930-1931, the first OUN cells were formed in Zhovkva, Matsoshin, Zashkiv, and other villages in the county. Their activities are coordinated by the county executive, headed in 1932 by Volodymyr Kasaraba. In the mid1930s, local cells («zveno» of 3-5 people formed a «bush» or «village») were subordinated to the Lviv and Rava districts of the OUN. OUN members denied any legal contacts with state authorities and prepared young people for a future uprising against the occupiers.

Under the leadership of S. Bandera, the development of the organizational structure of the OUN is being completed. The entire membership was divided into groups of five, created a hierarchical organizational system on a territorial basis with clear requirements for conspiracy. OUN members are increasingly involving young people from the countryside and the working class. Trainings for OUN county leaders, as well as individual members of the district and county executive, were also held.

The OUN (b) became the catalyst of state-building processes and attempts at national reconciliation and unification. Its active measures to spread the national idea to the east, train the military and concrete actions to create Ukrainian self-defense and armed forces, attempts to use the German occupation army to carry out its tasks and seek Ukraine's sovereignty became the cornerstone of the new occupiers. 
The OUN district continued the struggle during the Soviet period 1939-1941 Having accumulated considerable experience in the fight against the Polish occupying power. OUN members urged the local population not to join the collective farms ("state serfdom"), to sabotage the imposed Bolshevik authorities in the form of a large grain of meat. money, and sabotage deforestation and the construction of border fortifications. The Soviet system of education and denationalization, and more precisely the Russification of cultural life, were criticized.

It is revealed that the first OUN groups in the Ravska district were created at the initial stage of World War II. Our observations have led us to argue that the activities of the established subunit groups of the OUN in the territory of the Ravska district depend on the political situation in the region. It was the political situation that influenced the structural features and methods of activity of the Ravska district of the OUN.

\section{References:}

1. Havryliv, I. O. (2008). Bilshovytskyy teror na zakhidnoukrayinskykh zemlyakh (1939-1941) [Bolshevik terror in Western Ukraine in 1939-1941]. Derzhava ta armiya. Lviv: Vyd-vo Natsionalnoho un-tu Lvivska politekhnika, vol. 612, pp. 141-148.

2. Hrytsak, Y. A. (1996). Narys istoriyi Ukrayiny. Formuvannya modernoyi ukrayinskoyi natsiyi XIX-XX stolittya [Essay on the history of Ukraine. Formation of modern Ukrainian nations of the XIX-XX centuries]. Kyiv: Heneza, $360 \mathrm{p}$.

3. Hunchak, T. (2011). Klyuchovi problemy istoriohrafiyi Druhoyi svitovoyi viyny [Key problems of historiography of the Second World War]. Kyiv: UVS im. Yu. Lypy, $225 \mathrm{p}$.

4. Zajączkowski, M. (2015). Ukraińskie podziemie na Lubelszczyźnie w okresie okupacji niemieckiej 1939-1944 [Ukrainian dungeon in Lubelszczyń district in the German occupation 1939-1944]. Lublin; Warszawa: In-t Pamięci Narodowej Oddział w Lublinie ; In-t Studiów Politycznych PAN, 504 p.

5. Lytvyn, M. (1994). Zhovkivshchyna. Istorychnyi narys [Zhovkva district. Historical essay]. Zhovkva; Lviv; Baltymor: In-t ukrayinoznavstva im. I. Krypyakevycha, 1994. 325 p.

6. Lytvyn, M. (1997). Zhovkivshchyna. Istoryko-memuarnyy zbirnyk [Zhovkva district. Historical and memoir collection]. Zhovkva; Lviv; Baltymor: In-t ukrayinoznavstva im. I. Krypyakevycha, 1997. T. 3.365 p.

7. Koval, M. (1999). Ukrayina v Druhiy svitoviy $i$ Velykiy vitchyznyaniy viynakh (1939-1945) [Ukraine in the Second World War and the Great Patriotic War (1939-1945)].- Ukrayina kriz viky. Kyiv, T. 12. 336 p.

8. Kormych, L., \& Bahatskyy, V. (2000). Istoriya Ukrayiny vid naydavnishykh chasiv do 2000 roku [History of Ukraine from ancient times to 2000]. Kharkiv, $407 \mathrm{p}$. 
9. Kosyk, V. (1993). Ukrayina $i$ Nimechchyna u Druhiy svitoviy viyni [Ukraine and Germany in World War II]. Lviv; Paris; New-York: Naukove t-vo im. Shevchenka u Lvovi, $658 \mathrm{p}$.

10. Lysenko, O. (2004). Druha svitova viyna yak predmet naukovykh doslidzhen ta fenomen istorychnoyi pamyati [World War II as a subject of scientific research and the phenomenon of historical memory]. Ukrayinskyy istorychnyy zhurnal, no. 5, pp. 3-15.

11. Mykola Lytvyn, Oleksandr Lutskyy, Kim Naumenko (1999). 1939. Zakhidni zemli Ukrayiny [1939. Western lands of Ukraine]. Lviv: In-t ukrayinoznavstva im. Krypyakevycha NAN Ukrayiny, 152 p.

12. Litopys neskorenoyi Ukrayiny : dokumenty, materialy, spohady [Chronicle of unconquered Ukraine: documents, materials, memoirs] / [upor. Ya. Lyalka, R. Korytko, M. Onyshkevych ta in.]. Lviv: Halytska vydavn. spilka, 1997. Kn. 2. 664 p.

13. Lupiy, H. (1999). Podvyhy sotnyka «Ema» [The exploits of Captain Em]. Shlyakh do peremohy, 28 kvit., p. 6.

14. Mirchuk, P. (1953). Ukrayinska povstanska armiya 1942-1952 [Ukrainian Insurgent Army 1942-1952]. Munich: Tsytseron, $319 \mathrm{p}$.

15. Mirchuk, P. (2007). Narys istoriyi OUN. 1920-1939 roky [Essay on the history of the OUN. 1920-1939]. 3-edition. Kyiv: Ukr. vydav. spilka, 566 p.

16. Moroz, V. (2001). Pidpilna presa OUN i UPA na terytoriyi Lvivskoyi oblasti [The underground press of the OUN and UPA on the territory of Lviv area]. Vyzvolnyy shlyakh, vol. 9, pp. 44-48.

17. Moroz, V. (2002). «Buh» / Materiyaly do Entsyklopediyi «OUN i UPA» ["Bug" / Materials for the Encyclopedia "OUN and UPA"]. Vyzvolnyy shlyakh, vol. 12, pp. 32-38.

18. Na chatakh. Zhurnal dlya molodi. Rik 1, ch.1. Peredruk pidpilnykh vydan zh. 46 [On swallows. Magazine for young people. Year 1, part 1. Reprint of underground publications]. Krayovyy oseredok propahandy OUN [Regional Center for OUN Propaganda], 1946.

19. Nedoviz, D. (1996). Spomyny z molodykh lit [Memories from a young age]. Lviv: Chervona kalyna, $136 \mathrm{p}$.

20. Pavlyshyn, O. (2008). Lvivshchyna $v$ dobu Zakhidno-Ukrayinskoyi Narodnoyi Rekspubliky (1918-1919) [Lviv region in the days of the Western Ukrainian People's Republics (1918-1919)]. Lviv: Litopys, 224 p.

21. Zinkevych, R. (1997). Partyzanskymy dorohamy z komandyrom Zaliznyakom [Guerrilla roads with Commander Zalizniak]. Drohobych: Vidrodzhennya, $360 \mathrm{p}$.

22. Patrylyak, I. K. (2012). «Vstan i borys! Slukhay i vir...»: ukrayinske natsionalistychne pidpillya ta povstanskyy rukh (1939-1960 rr.): monohrafiya ["Get up and fight! Listen and believe...": Ukrainian nationalist underground and insurgent movement (1939-1960): monograph]. Lviv: Chasopys, 276 p.

23. Patrylyak, I. K. (2012). «Peremoha abo smert»: ukrayinskyy vyzvolnyy rukh u 1939-1960-kh rr. ["Victory or death": the Ukrainian liberation movement in the 1939-1960s]. Lviv: Chasopys, 512 p.

24. Pelekh, T. (1988). Moyi molodi lita u vyri borotby [My young summers are in a whirlpool of struggle]. Munich; Toronto: Ukr. edition, $238 \mathrm{p}$. 
25. Romanyuk, M. (2012). Stvorennya ta diyalnist Zolochivskoyi okruhy OUN (1937-1941) [Creation and activity of Zolochiv district of OUN (1937-1941)]. Ukrayina: kulturna spadshchyna, natsionalna svidomist, derzhavnist, vol. 22, pp. 347-363.

26. Rusnachenko, A. (2002). Narod zburenyy: Natsionalno-vyzvolnyy rukh $v$ Ukrayini y natsionalni rukhy oporu v Bilorusiyi, Lytvi, Latviyi, Estoniyi u 1940-50$k h$ rokakh [The people are upset: the National Liberation Movement Ukraine and national resistance movements in Belarus, Lithuania, Latvia, and Estonia in 1940-50s]. Kyiv: Universytetske vyd-vo «Pulsary», 519 p.

27. Semenenko, V., \& Radchenko, L. (1999). Ystoriya Ukrayny [History of Ukraine]. 2-ed. Kyiv, 400 p.

28. Stasyuk, O. Y. (2011). Pidpilni drukarni OUN (1941-1953) [OUN underground printing houses (1941-1953)]. Lviv: In-t ukrayinoznavstva im. I. Krypyakevycha NAN Ukrayiny, 296 p.

29. Stetskevych, V. (2002). Istoriya Ukrayiny v roky viyny 1941-1945 rr.: teoretychnyy kontekst osmyslennya (deyaki aspekty problemy) [History of Ukraine during the war of 1941-1945: theoretical context of comprehension (some aspects of the problem)]. Storinky voyennoyi istoriyi Ukrayiny [Pages of military history of Ukraine]. / vidp. red. V. A. Smoliy. NAN Ukrayiny. Kyiv: In-t istoriyi Ukrayiny, vol. 6, pp. 25-31.

30. Subtelnyi, O. (1991). Ukraina: istoriya [Ukraine: history]. Kyiv: «Lybid», 510 p.

31. Turchenko, F. H. (1994). Novitnya istoriya Ukrayiny: 2 ch. [Recent history of Ukraine: 2 chapters]. Kyiv, ch. 1, 384 p.

32. Shankovskyi, L. (1996). Ukrayinska Povstancha Armiya. Istoriya ukrayinskoho viyska. 1917-1995 [Ukrainian Insurgent Army. History of Ukrainian military. 1917-1995]. Lviv: Svit, 715 p.

33. Yavorivskyi, Ye. (2002). Nova Skvaryava. Istoryko-krayeznavche doslidzhennya [Historical and local lore research]. Lviv: Liga-Press, $192 \mathrm{p}$. 